\title{
IMPLEMENTASI EXTREME PROGRAMMING PADA SISTEM INVENTORY MEBEL PADA CV PROFESTAMA KURNIA NISA
}

\author{
Mesri Silalahi' ${ }^{1}$, Yulia ${ }^{2}$ \\ Jalan R. Soeprapto, Muka Kuning - Batam \\ mesri@puterabatam.ac.id ${ }^{1}$, yuliaedwar2407@gmail.com²
}

\begin{abstract}
The furniture business is one of the profitable business opportunities, this is due to population growth which continues to increase so that residential needs also continue to increase which automatically results in an increase in demand for furniture products. One of the business units in the field of furniture which is currently developing in Batam, namely CV Profestama Kurnia Nisa, the daily operational process is directly controlled by the owner and assisted by several employees consisting of sales, admin and warehouse parts as well as delivery. In managing furniture supplies, CV Profestama Kurnia Nisa does not have a special method. The owner usually asks directly to the employee regarding the sale, then it will be adjusted to the purchase note from the supplier, then it will be matched with the stock in the warehouse, then this data will be recorded in the owner's notebook. This resulted in the difficulty of knowing various things related to the supply of furniture in the Warehouse and on display, especially when the owner was not in place or was out of town. This study aims to design a web-based furniture inventory system at CV Profestama Kurnia Nisa and implement a web-based furniture inventory system on CV Profestama Kurnia Nisa. The design method used is Extreme Programming (XP) which consists of several stages, namely: Planning, Design, Coding, Testing, Software increment. The newly designed system can be accessed online so that the owner can easily find out the number of furniture and when the stock is less then direct orders can be made to the supplier even though the owner is out of town.
\end{abstract}

Keywords: Website, Extreme Programming (XP), Inventory, Inventory Sistem

\section{Abstrak}

Bisnis furniture merupakan salah satu peluang usaha yang menguntungkan, hal ini disebabkan pertumbuhan penduduk yang terus meningkat sehingga kebutuhan tempat tinggal juga terus mengalami peningkatan yang secara otomatis berdampak pada peningkatan permintaan produk mebel. Salah satu unit usaha dalam bidang furniture yang saat ini berkembang di Batam yaitu CV Profestama Kurnia Nisa, proses operasional seharihari langsung dikendalikan oleh owner serta dibantu oleh beberapa karyawan yang terdiri dari sales, admin dan bagian gudang yang sekaligus bagian pengantaran. Dalam pengelolaan persediaan furniture, CV Profestama Kurnia Nisa tidak mempunyai cara yang khusus. Owner biasanya menanyakan secara langsung kepada karyawan yang berkaitan mengenai penjualan kemudian akan disesuaikan dengan nota pembelian dari supplier selanjutnya akan dicocokkan dengan stok di gudang selanjutnya data ini akan dicatat di dalam buku catatan owner. Hal ini mengakibatkan sulitnya mengetahui berbagai hal terkait 
dengan persediaan furniture yang ada di Gudang maupun yang dipajang, khususnya ketika owner tidak berada di tempat atau sedang berada di luar kota. Penelitian ini bertujuan merancang sistem inventory mebel berbasis web pada CV Profestama Kurnia Nisa serta mengimplementasikan sistem inventory mebel berbasis web pada CV Profestama Kurnia Nisa. Metode perancangan yang digunakan yaitu Extreme Programming (XP) yang terdiri dari beberapa tahapan yaitu: Planning (Perencanaan), Design (Perancangan), Coding (Pengkodean), Testing (Pengujian), Software increment (Peningkatan Perangkat Lunak). Sistem yang baru dirancang dapat diakses secara daring sehingga owner dapat dengan mudah mengetahui jumlah furniture dan ketika stok sudah kurang maka langsung dapat dilakukan pemesanan kepada supplier walaupun owner sedang berada di luar kota.

Kata kunci: Website, Extreme Programming, Inventory, Sistem Inventory

\section{PENDAHULUAN}

Bisnis furniture atau mebel merupakan salah satu peluang usaha yang mengungtungkan, hal ini disebabkan karna pertumbuhan penduduk yang terus meningkat sehingga kebutuhan akan tempat tinggal juga terus mengalami peningkatan yang secara otomatis berdampak pada peningkatan permintaan produk mebel. Para pebisnis di bidang furniture di Batam juga semakin berlombalomba dalam memasarkan produknya, berbagai strategi pemasaran mereka lakukan untuk meningkatkan penjualan salah satunya dengan melakukan promosi. Berbagai produk mebel juga ditawarkan sesuai kebutuhan masyarakat, baik produk baru maupun bekas. Kualitas produk-produk mebel yang ditawarkan sangat bervariasi mulai dari kualitas standar sampai premium disesuiakan dengan daya beli masyarakat. Beberapa produk mebel yang biasanya dijual di tokotoko Furniture di Batam seperti Furniture kamar, Set meja makan, Set ruang tamu, Sofa, Tempat tidur dan lain sebagainya.

Strategi pemasaran perusahaan untuk meningkatkan penjualan tidak akan berfungsi dengan maksimal apabila tidak didukung oleh pengelolaan persediaan yang baik, karena pengelolaan persediaan adalah salah satu hal yang sangat penting dalam sebuah perusahaan, disebabkan karena persediaan adalah salah satu aset perusahaan yang sangat penting yang membawa pengaruh langsung terhadap kemampuan perusahaan dalam memperoleh pendapatan[1]. Hampir setiap perusahaan dipastikan mempunyai metode khusus dalam pengelolaan persediaan. Perusahaan yang tidak mengelola persediaan dengan baik maka akan sangat besar kemungkinan mengalami kegagalan. Banyak cara yang dilakukan perusahaan untuk mengelola persediaan, baik yang bersifat manual maupun komputerisasi. Dalam pengelolaan persediaan secara komputerisasi, perusahaan banyak yang membangun sistem khusus yang sesuai dengan perkembangan teknologi saat ini yang memungkinkan pengaksesan dimana saja. Banyak perusahaan yang sudah memanfaatkan sebuah sistem dalam pengelolaan persediaan mereka, tidak terkecuali perusahaan atau unit usaha di bidang mebel.

Salah satu unit usaha dalam bidang furniture atau mebel yang berkembang di Batam yaitu CV Profestama Kurnia, CV ini menjual berbagai jenis peralatan furniture diantaranya Sofa, Kursi, Furniture ruang makan, Set Bed Furniture, Lemari, Buffet, dan lain sebagainya. Proses penjualan biasanya dilakukan dengan 
cara memajang beberapa contoh terlebih dahulu di Toko kemudian jika ada pelanggan yang akan membeli maka mereka akan diberikan pilihan yaitu mengambil furniture yang sudah dipajang atau barang diambil dari gudang. Untuk setiap jenis furniture disediakan stok di Gudang dengan jumlah stok sesuai dengan tingkat permintaan pelanggan terhadap barang tersebut. Apabila sebuah furniture permintaannya banyak maka stok di gudang akan lebih banyak. Dalam pengelolaan persediaan furniture oleh owner CV Profestama Kurnia Nisa tidak mempunyai cara yang khusus. Owner biasanya hanya menanyakan secara langsung ke karyawan yang berkaitan mengenai penjualan kemudian akan disesuaikan dengan nota pembelian dari supplier selanjutnya akan disesuaikan dengan stok di gudang dan kemudian data ini akan dicatat di dalam buku catatan owner CV Profestama Kurnia Nisa. Hal ini mengakibatkan sulitnya mengetahui berbagai hal terkait dengan persediaan furniture baik yang ada di Gudang maupun yang dipajang khususnya ketika owner sedang berada berada di luar kota. Selain persediaan furniture yang baru, CV Profestama Kurnia Nisa juga memiliki persediaan furniture bekas, hal ini dikarenakan CV ini melayani sistem penjualan kredit dari toko secara langsung jadi ketika ada pelanggan yang menunggak dan sudah melampau batas pembayaran yang sudah ditentukan maka peralatan furniturenya akan ditarik. Oleh karena itu perlu adanya sebuah sistem yang mengelola persedian furniture CV Profestama Kurnia Nisa sehingga dapat mempermudah owner dalam mengetahui berbagai hal tentang persediaannya. Kemudian dengan adanya sistem yang dapat diakses secara online maka owner juga dapat dengan mudah mengetahui jumlah furniture dan ketika stok sudah kurang maka langsung dapat melakukan pemesanan kepada supplier walaupun owner sedang berada di luar kota. Oleh karena itu, penelitian ini bertujuan untuk merancang sistem Inventory mebel berbasi web pada CV Profestama Kurnia Nisa, mengimplementasikan sistem Inventory mebel berbasi web pada CV Profestama Kurnia Nisa.

Sistem adalah kumpulan elemen-elemen yang saling berinteraksi dalam mencapai suatu tujuan tertentu [2]. Sistem juga menunjukkan berbagai kejadian dan merupaan kesatuan nyata dari suatu objek nyata, seperti tempat, benda, dan orang-orang yang betul-betul ada dan terjadi. informasi sebagai suatu data yang telah diolah menjadi bentuk yang lebih berguna dan lebih berarti bagi penggunanya. Sedangkan Tata Sutabri menjelaskan bahwa data yang telah diolah atau diinterpretasikan sehingga dapat digunakan dalam proses pengambilan keputusan. Sedangkan persediaan adalah barang-barang yang disimpan untuk digunakan atau untuk dijual [3]. Persediaan terdiri dari beberapa jenis yaitu persediaan bahan baku, persediaan barang setengah jadi dan persediaan barang jadi. Persediaan bahan baku dan bahan setengah jadi disimpan sebelum digunakan atau dimasukkan ke dalam proses produksi, sedangkan persediaan barang jadi atau barang dagangan disimpan sebelum dijual atau dipasarkan.

Godana dan Ngugi mendefinisikan manajemen inventory sebagai semua persediaan yang tersedia untuk memenuhi permintaan. Manajemen inventory terdiri dari serangkaian keputusan yang berfungsi untuk memenuhi kebutuhan terhadap permintaan pasokan produk dan bahan baku dalam jangka waktu dan 
biaya tertentu, untuk mencapai tujuan layanan tertentu, mengamati karakteristik produk, operasi, dan permintaan. Secara umum untuk memperoleh persediaan (inventory) dibutuhkan jangka waktu yang sesuai dengan persediaan yang sudah ada di perusahaan, sehingga dapat mengakibatkan terjadinya kekurangan stok [4].

Dalam melakukan operasional sehari-hari, masing-masing perusahaan seperti perusahaan jasa, dagang maupun manufaktur sudah dapat dipastikan memerlukan persediaan atau inventory. Hal ini dikarenakan tanpa persediaan perusahaan akan menghadapi resiko besar yaitu permintaan produk oleh pelanggan tidak terpenuhi tepat waktu, sebaliknya jika perusahaan memiliki persediaan yang terlalu banyak maka akan dapat menimbulkan besarnya biaya penyimpanan. Persediaan merupakan stock yang dibutuhkan perusahaan untuk mengatasi adanya fluktuasi permintaan. Persediaan dalam proses produksi diartikan sebagai sumber daya menganggur, hal ini disebabkan sumber daya tersebut masih menunggu dan belum digunakan pada proses berikutnya. Persediaan juga merupakan barang-barang mentah, material atau barang jadi yang disimpan untuk digunakan pada masa yang akan datang atau dalam kurun waktu tertentu. Persediaan barang dalam suatu perusahaan merupakan suatu hal sangat penting, hal ini sebagai langkah dalam menghadapi perubahan pasar produksi serta mengantisipasi perubahan harga permintaan barang tersebut dalam jumlah yang banyak. Lebih lanjut dijelaskan bahwa pengertian persediaan atau inventory sebagai sejumlah sumber daya baik berbentuk bahan mentah ataupun barang jadi yang disediakan perusahaan untuk memenuhi permintaan dari pelanggan. Sedangkan dalam pengertian lainnya inventory adalah suatu metode dalam memanajemen material yang berkaitan dengan persediaan[5].

Extreme Programming merupakan salah satu teknik pengembangan software yang cukup sederhana, komunikasi, dan umpan balik yang baik. Extreme Programming dirancang untuk tim kecil yang akan mengembangkan software dengan waktu yang pengambangan yang dibutuhkan cepat serta dalam lingkungan yang cepat berubah juga[6]. Metode XP merupakan salah satu teknik pengembangan software yang cukup ringan dan merupakan salah satu agile methods yang dipelopori oleh Kent Beck, Ron Jeffries, dan Ward Cunningham. XP termasuk salah satu agile methods yang terbanyak digunakan dan merupakan sebuah pendekatan yang sangat terkenal. Sasaran $X P$ adalah tim kecil sampai menengah saja, tidak perlu menggunakan sebuah tim yang besar. Hal ini ditujukan untuk menghadapi requirements yang tidak terlalu penting maupun perubahan-perubahan requirements yang sangat cepat. Kelebihan yang dimiliki XP dibandingkan dengan metode agile yang lain yaitu teknik ini sangat cocok untuk proyek yang memerlukan perubahan dengan cepat, proyek yang memiliki resiko tinggi serta proyek dengan tantangan yang baru, tim programmer paling sedikit terdiri dari 2-10 orang, mampu mengotomatisasikan testing, serta adanya peran pelanggan secara langsung. Adapun tahapan-tahapan yang dilakukan yaitu Planning, Design, Coding, Testing [7].

Unified Modeling Language (UML) adalah salah satu bahasa pemodelan perangkat lunak berorientasi objek (OOD) yang difungsikan untuk 
menyederhanakan berbagai permasalahan yang rumit sehingga dapat mempermudah pengguna dalam mempelajari dan memahahaminya. Sholiq menjelaskan notasi UML merupakan hasil kolaborasi dari Grady Booch, DR.James Rumbough, Ivar Jacobson, Rebecca Wirfs- Brock, Peter Yourdon, dan lainnya. UML terdiri dari beberapa diagram yang menunjukkan berbagai aspek dalam sistem [8]. PHP merupakan salah satu bahasa pemrograman web atau scripting language yang dapat berjalan di server. Pertama sekali dibangun oleh Rasmus Lerdorf, dengan tujuan awalnya untuk menghitung jumlah pengunjung pada homepage nya. PHP pertama sekali disebut FI (Form Interpreter), artinya sekumpulan script yang digunakan untuk mengolah data form dari web [9].

MySQL adalah turunan dari salah satu konsep utama dalam basis data SQL (Structured Query Language). SQL merupakan sebuah konsep pengoperasian basis data terutama untuk proses seleksi, pemasukan, pengubahan dan penghapusan data yang dimungkinkan dapat dikerjakan dengan mudah dan otomatis[10]. XAMPP adalah tool yang menyediakan paket perangkat lunak ke dalam satu buah paket. Dengan menginstall XAMPP maka pengguna tidak perlu melakukan instalasi dan konfigurasi web server Apache, PHP dan MySQL secara manual. XAMPP secara langsung menginstalasi dan mengkonfigurasikannya secara atau auto konfigurasi[10].

\section{METODOLOGI PENELITIAN}

Model perancangan yang dipakai pada penelitian ini adalah Extreme Programming (XP). Tahapan-tahapan pada metode Extreme Programming seperti gambar berikut ini:

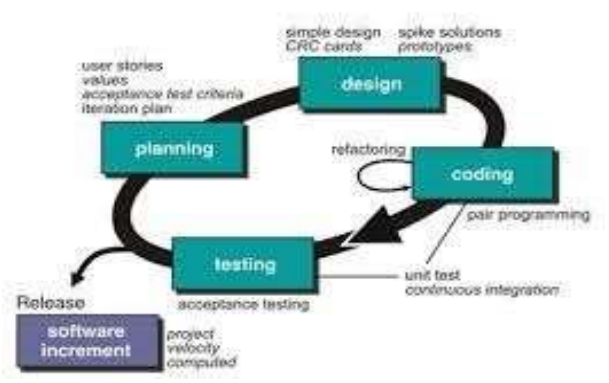

Sumber: Adi Supriyatna [11]

Gambar 1. Tahapan dalam metode extreme programming

Tahapan dalam dalam perancangan sistem inventory mebel pada CV Profestama Kurnia Nisa dengan metode extreme programming akan dijelaskan sebagai berikut:

a. Planning (Perencanaan)

Tahap ini merupakan kegiatan memahami proses bisnis yang sedang berjalan serta memahami proses bisnis untuk sistem yang akan dibangun sehingga memperoleh gambaran yang jelas mengenai fitur utama, fungsionalitas sistem serta output yang diharapkan. Dalam pembangunan sistem inventory mebel pada CV Profestama Kurnia Nisa, hal-hal yang dilakukan pada tahapan ini dimulai dari identifikasi permasalahan yang dihadapi pada sistem yang sedang 
berjalan, kemudian menganalisis kebutuhan pengguna terhadap sistem yang akan dibangun.

b. Design (Perancangan)

Perancangan dilakukan dengan membuat sistem model berdasarkan hasil analisis pada tahap sebelumnya. Pemodelan basis data juga dibuatkan pada tahapan ini yang bertujuan untuk menggambarkan hubungan antar data maupun antar proses yang akan dilakukan. Pemodelan sistem dilakukan dengan menggunakan Unified Modelling Language (UML). Beberapa diagram yang digunakan dalam perancangan ini adalah Use-Case Diagram, Activity Diagram, Component Diagram dan Deployment Diagram.

c. Coding (Pengkodean)

Setelah design dilakukan makan design tersebut diimplementasikan kedalam kode program yang nantinya akan menghasilkan sistem inventory mebel pada CV Profestama Kurnia Nisa. Dalam membangun sistem inventory mebel ini digunakan bahasa pemrograman PHP yang dikombinasikan dengan HTML, CSS dan Javascript dan basis data menggunakan MySQL.

d. Testing (Pengujian)

Proses yang dilakukan pada tahap ini adalah menguji sistem inventory mebel yang dibangun. Beberapa hal yang dilakukan pengujian yaitu: fungsionalitas keseluruhan dari sistem informasi mebel. Metode yang digunakan untuk menguji sistem informasi mebel yaitu menggunakan Black-Box Testing yaitu dengan melakukan pengujian terhadap input dan output dari sistem inventory mebel.

e. Software increment (Peningkatan Perangkat Lunak)

Tahap ini adalah merupakan pengembangan sistem yang sudah dibuat secara bertahap yang bertujuan untuk meningkatkan fungsionalitas dari sistem. Dalam penelitian ini tahap Software increment (Peningkatan Perangkat Lunak) tidak dilakukan dikarenakan software yang dibangun masih baru akan diterapkan.

\subsection{Teknik Pengumpulan Data}

Data dikumpulkan dengan teknik pengumpulan data sebagai berikut:

a. Observasi

Observasi ini ditujukan untuk mengamati objek penelitian. Dalam kegiatan ini peneliti bersama anggota peneliti mengunjungi secara langsung objek penelitian dan untuk mendapatkan data-data yang dibutuhkan. Pada teknik ini juga peneliti mengunjungi secara langsung CV Profestama Kurnia Nisa.

b. Wawancara

Teknik pengumpulan data lainnya yang dilakukan peneliti yaitu dengan melakukan wawancara dengan owner CV Profestama Kurnia Nisa dan beberapa karyawan CV tersebut 


\subsection{Analisis Sistem yang Sedang Berjalan}

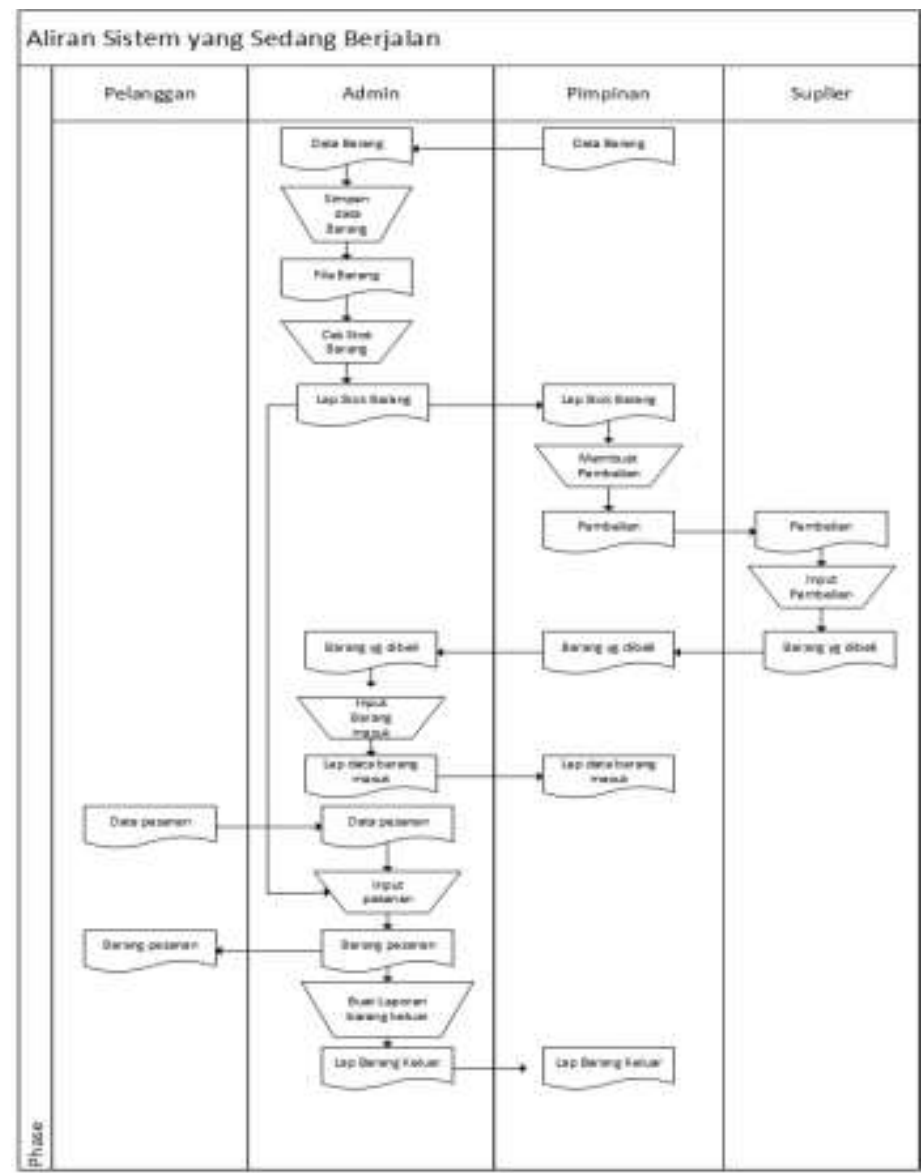

Gambar 2. Aliran Sistem Informasi yang Lama

\section{HASIL DAN PEMBAHASAN}

\subsection{Hasil}

Dalam merancang sistem inventory mebel pada CV Profestama Kurnia Nisa, maka tahap awal tahap awal yang harus dilakukan yaitu memahami permasalahan yang dihadapi terkait inventory mebel dan selanjutnya menetapkan tujuan dari penelitian yang dilakukan.

\subsubsection{Analisa Sistem yang Baru}

Peneliti melakukan beberapa pengubahan pada sistem yang baru yang mana pada sistem inventory yang sedang berjalan, semua kegiatan pengelolaan data-data persediaan seluruhnya dilakukan secara manual sedangkan pada sistem yang barus proses dilakukan menggunakan sistem. Aliran sistem informasi yang baru sistem inventory mebel pada CV Profestama Kurnia Nisa sebagai berikut: 


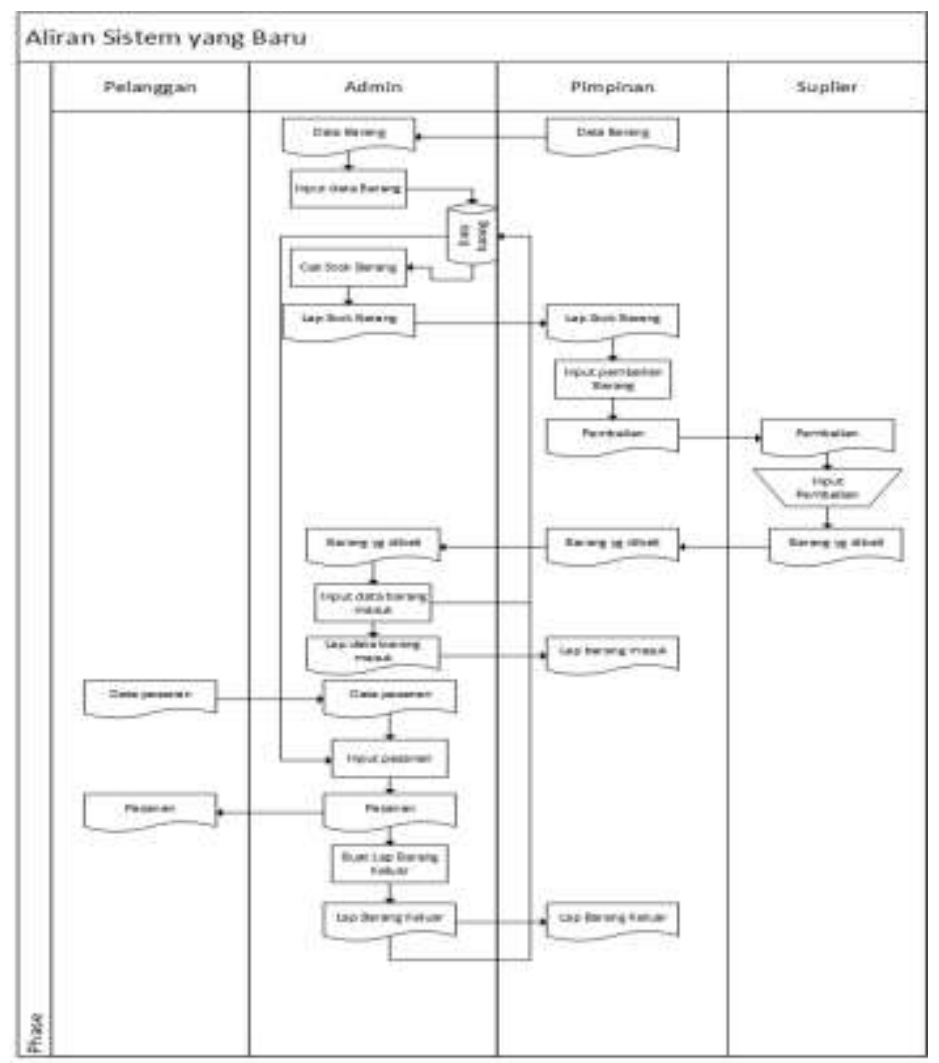

Gambar 3. Aliran Sistem Informasi yang Baru

\subsubsection{Usecase Diagram}

Usecase diagram yang akan diimplementasikan pada sistem yang baru sebagai berikut:

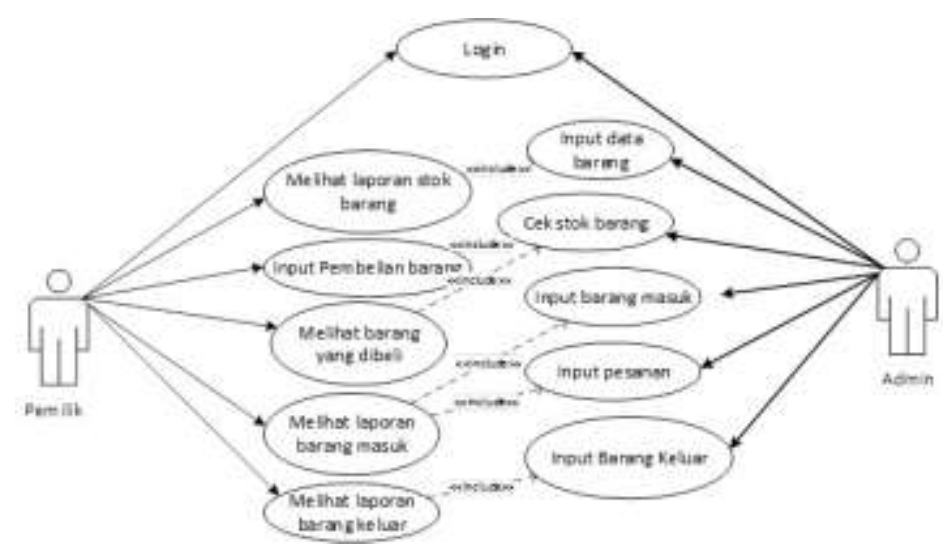

Gambar 4. Usecase diagram

\subsubsection{Activity Diagram}

Menggambarkan aktivitas utama dalam sistem setelah membuka aplikasi. Beberapa activity diagram pada sistem inventory mebel Pada CV Profestama Kurnia Nisa sebagai berikut: 


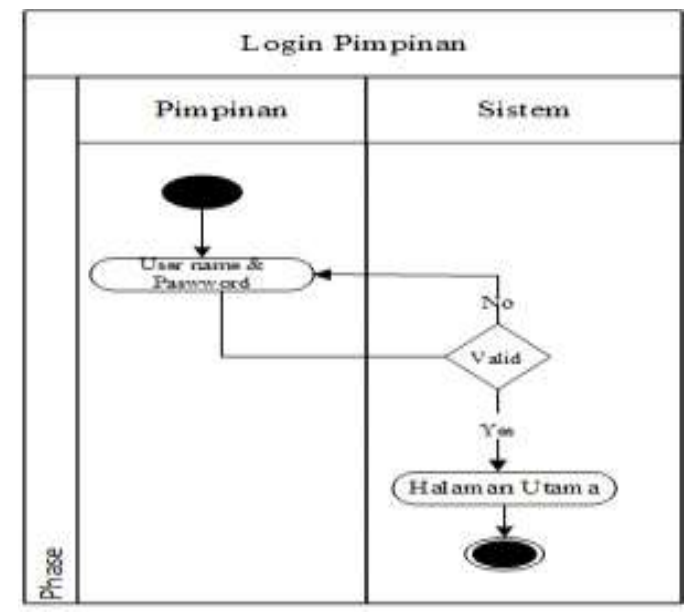

Gambar 5. Activity diagram Login

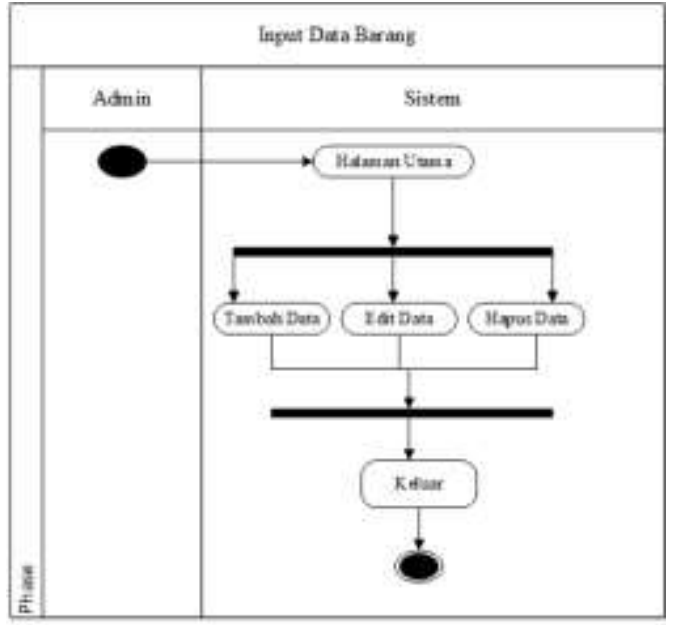

Gambar 6. Activity diagram Input Data Barang

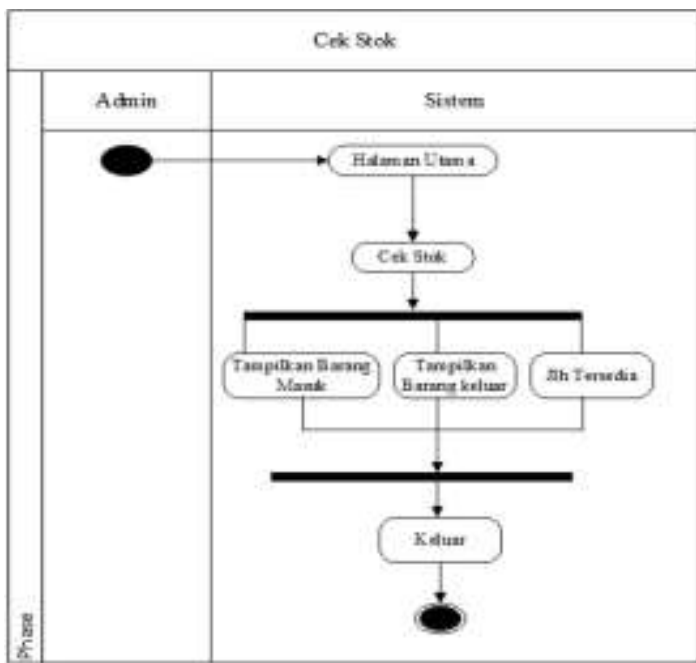

Gambar 7. Activity diagram Cek Stok 


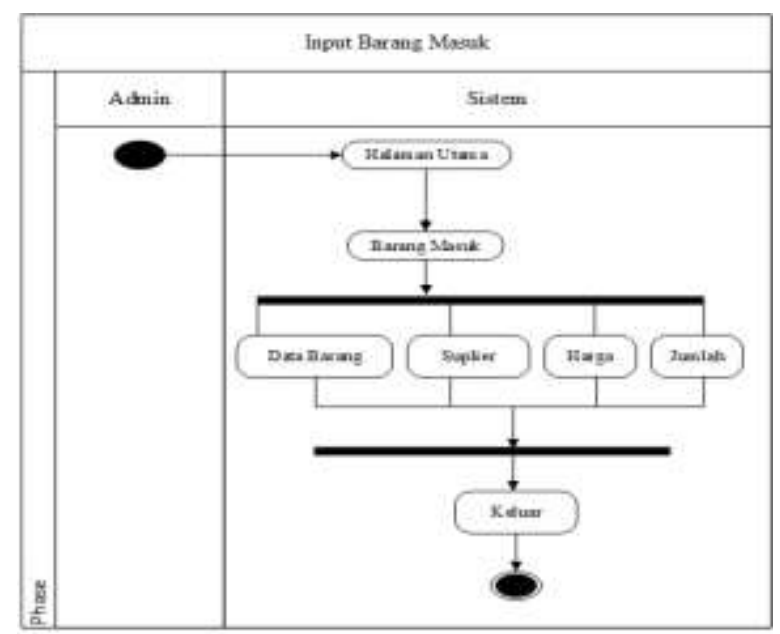

Gambar 8. Activity diagram Input Barang Masuk

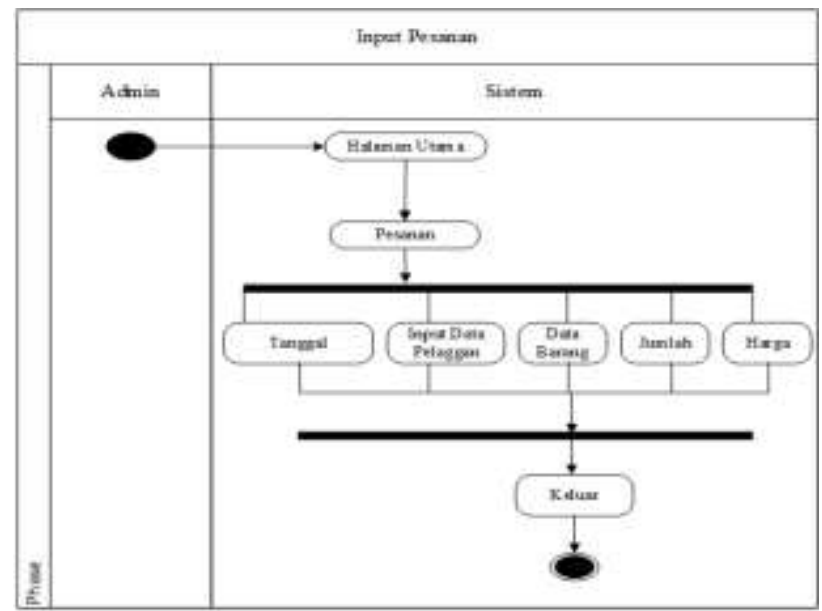

Gambar 9. diagram Input Pesanan

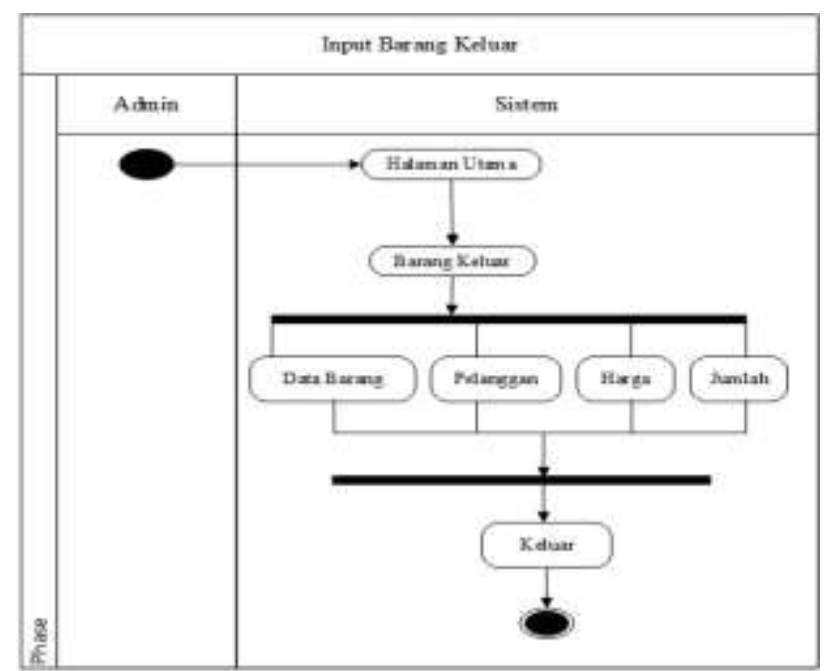

Gambar 10. Activity diagram Input Barang Keluar 


\subsubsection{Sequence Diagram}

Menggambarkan interaksi antara pemilik dengan sistem pada proses login. Sequence diagram dapat dilihat pada gambar berikut:

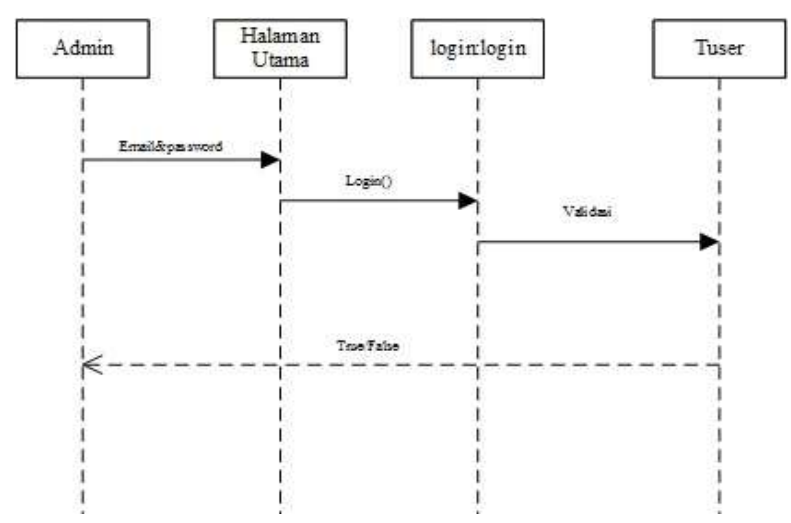

Gambar 11. Sequence diagram login

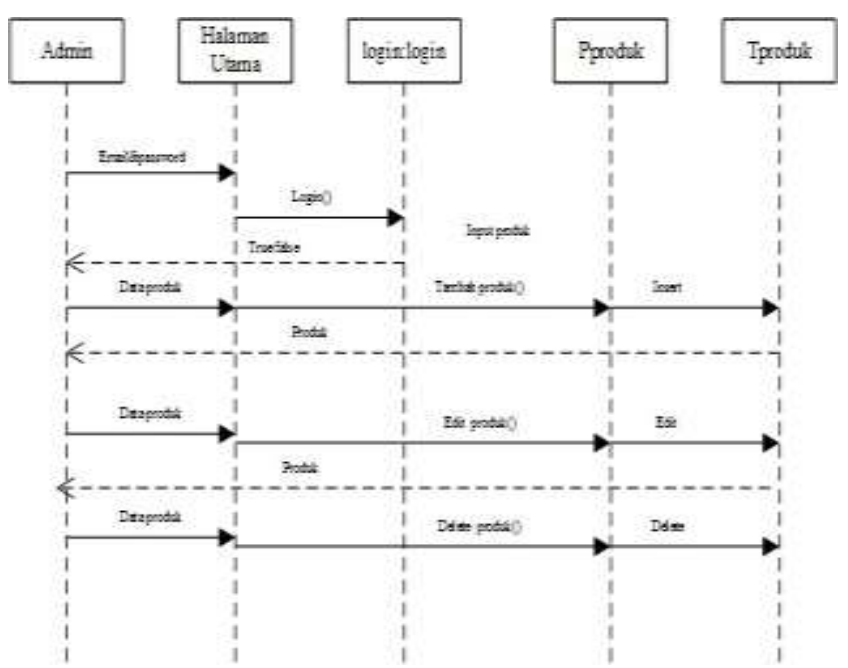

Gambar 12. Sequence diagram Input Barang

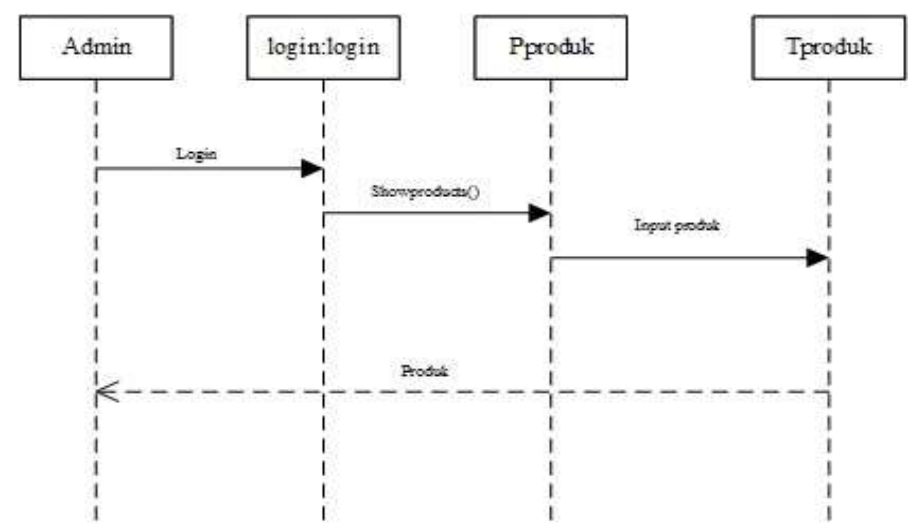

Gambar 13. Sequence diagram Cek Stok 


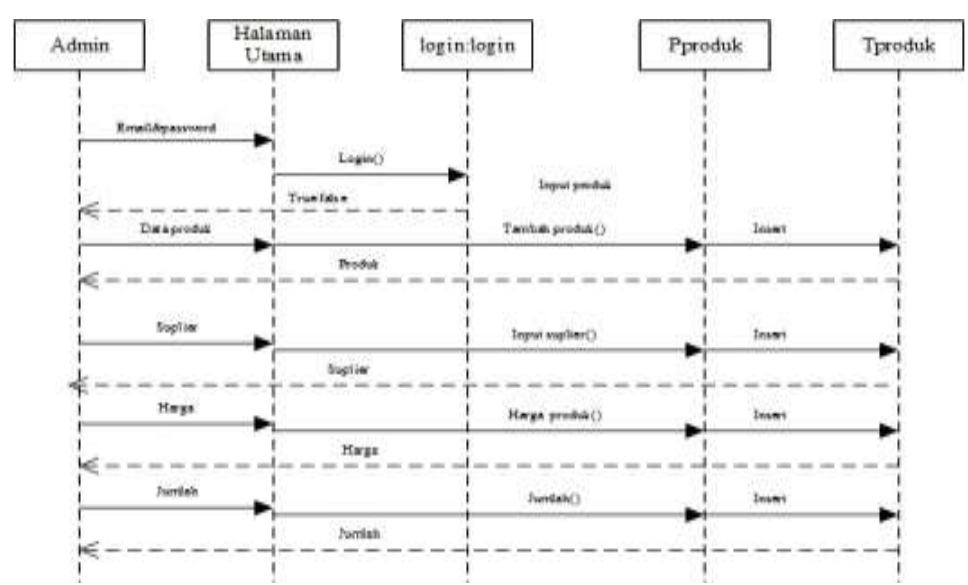

Gambar 14. Sequence diagram Barang Masuk

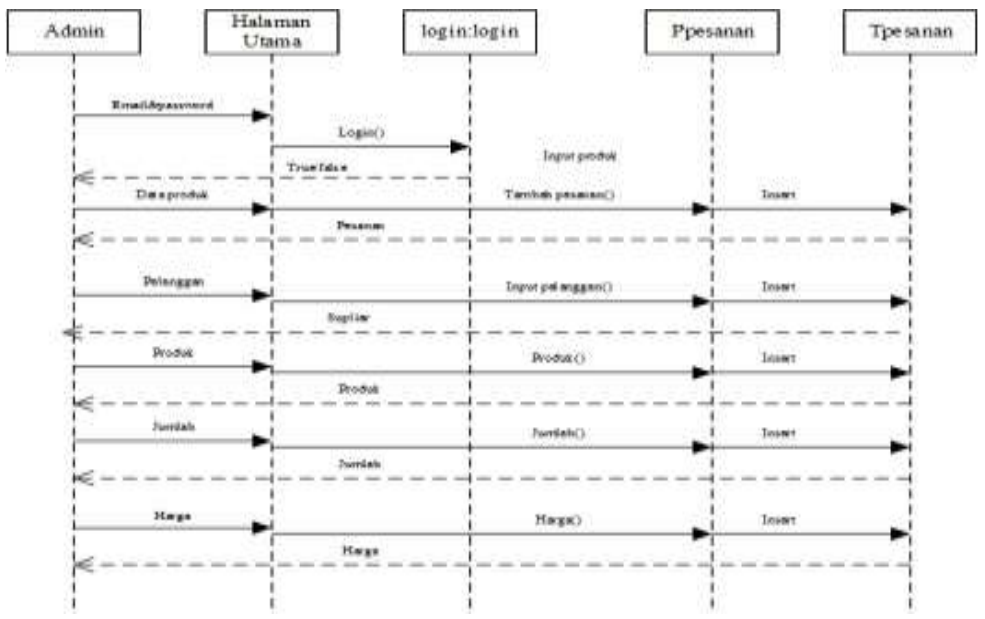

Gambar 15. Sequence diagram Pesanan

3.1.5. Tampilan sistem inventory mebel

\section{PROFESTAMA KURNIA NISA}

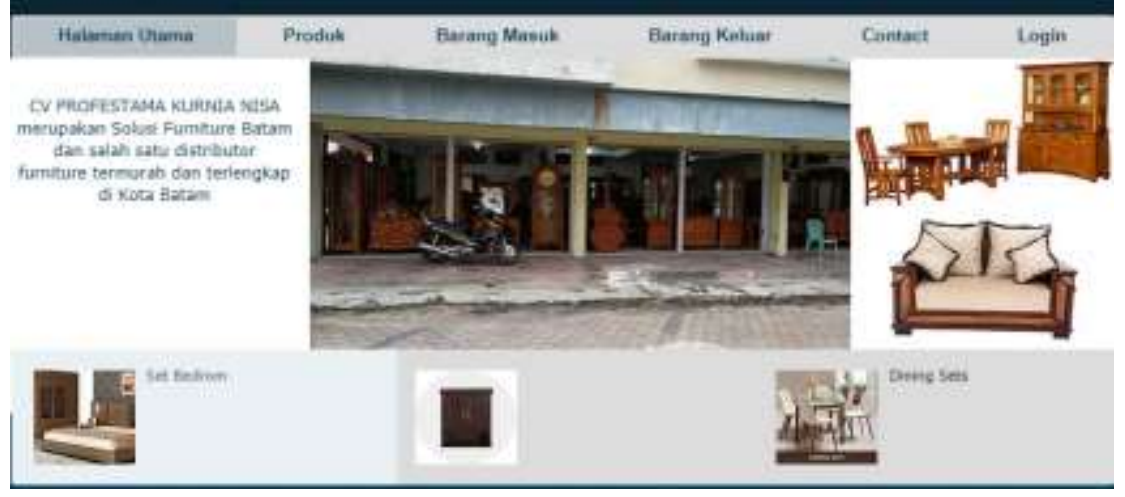

Gambar 16. Tampilan Sistem Inventory Mebel 


\subsection{Pembahasan}

Implementasi Extreme Programming Pada Sistem Inventory Mebel Pada CV Profestama Kurnia Nisa mempunyai beberapa kelebihan salah satunya yaitu simplicity (kesederhanaan). Secara umum metode extreme programming tidak jauh berbeda dengan metode waterfall, namun dalam metode ini perancangan lebih sederhana sehingga dalam perancangan yang dilakukan membutuhkan waktu yang lebih singkat dan praktis. Apabila dibandingkan sistem lama dengan yang baru maka perbandingannya dapat dilihat sebagai berikut:

Tabel 1. Perbandingan sistem

\begin{tabular}{llll}
\hline No & Sistem Lama & Sistem Baru \\
\hline 1 & $\begin{array}{l}\text { Tidak terdapat pencatatan } \\
\text { inventory/persediaan }\end{array}$ & Terdapat pencatatan persediaan \\
2 & $\begin{array}{l}\text { Tidak terdapat pencatatan barang } \\
\text { masuk }\end{array}$ & Terdapat pencatatan barang masuk \\
3 & $\begin{array}{l}\text { Tidak terdapat pencatatan barang } \\
\text { keluar }\end{array}$ & $\begin{array}{l}\text { Tidak terdapat pencatatan barang } \\
\text { keluar } \\
\text { Tidak dapat mengecek persediaan } \\
\text { secara otomatis }\end{array}$ & $\begin{array}{l}\text { Pada menu produk dapat mengecek } \\
\text { jumlah stok secara otomatis }\end{array}$ \\
\hline
\end{tabular}

Apabila dilihat dari segi efisiensi dan efektivitas maka sistem yang baru memberikan beberapa keuntungan sebagai berikut

a. Segi Efisiensi

Beberapa keunggulan dalam segi efisiensi dengan diimplementasikannya sistem yang baru, antara lain:

1. Pemilik CV Profestama Nisa dapat mengetahui dengan cepat jumlah stok minimal mebel sehingga dapat menghindari kekosongan stok.

2. Admin dapat melakukan input data-data barang dengan cepat.

b. Segi Efektivitas

Terdapat beberapa keunggulan dalam segi efektivitas dengan diimplementasikannya sistem yang baru, antara lain:

1. Dengan adanya sistem informasi yang baru maka pengelolaan persediaan lebih baik.

2. Dengan adanya sistem yang baru dapat mempermudah pimpinan sebagai pemilik dalam pengambilan keputusan.

\section{SIMPULAN}

Adapun kesimpulan dari penelitian ini yaitu sebagai berikut :

a. Sistem Inventory Mebel pada CV Profestama Kurnia Nisa telah dirancang menggunakan PHP sehingga dapat mempermudah pimpinan dalam pengelolaan persediaan mebel sehingga tidak terjadi penumpukan maupun kekurangan stok mebel.

b. Sistem Inventory Mebel pada CV Profestama Kurnia Nisa telah diimplementasikan menggunakan metode Extreme programming dimana 
menggunakan metode ini dapat meningkatkan efisiensi dan efektivitas dalam perancangan sistem.

\section{DAFTAR PUSTAKA}

[1] RUDIANTO, Pengantar Aluntansi Konsep \& Teknik Penyusunan Laporan Keuangan. Jakarta: PT Gelora Aksara Pratama, 2012.

[2] D. Susianto and R. A. Guntoro, "RANCANG BANGUN SISTEM INFORMASI GEOGRAFIS DAERAH TITIK RAWAN KECELAKAAN DI PROVINSI LAMPUNG,” J. Cendikia, vol. 14, no. 1, pp. 19-25, 2017.

[3] D. Setyorini and F. N. Hakim, "RANCANG BANGUN SISTEM INFORMASI PERSEDIAAN GUDANG UNTUK ANALISIS KEBUTUHAN BARANG ( STUDI KASUS PADA DINAS PENERANGAN JALAN DAN PENGELOLAAN REKLAME KOTA SEMARANG ) Q = Maks - Min," J. Teknol. Inf. dan Komun., vol. 7, no. 2, pp. 27-36, 2016.

[4] E. Kurniawan, A. Susilawati, and Do. Sofyan Arief, "RANCANG BANGUN SISTEM MANAJEMEN INVENTORY / PERLENGKAPAN PERALATAN LABORATORIUM TEKNIK MESIN UNIVERSITAS RIAU," Jom FTEKNIK, vol. 3, no. 2, pp. 1-6, 2016.

[5] A. Heryanto, H. Fuad, and D. Dananggi, "Rancang Bangun Sistem Informasi Inventory Barang Berbasis Web Studi Kasus di PT . Infinetworks Global Jakarta," J. SISFOTEK Glob., vol. 4, no. 2, pp. 32-35, 2014.

[6] B. A. Candra, K. Muludi, and A. R. Irawati, "Rancang Bangun Sistem Informasi Manajemen Terpadu ( SIMANTEP) Online PT . PLN ( Persero ) Sektor Pembangkitan Tarahan Lampung Dengan Metode Extreme Programming," J. komputasi, vol. 1, no. 1, pp. 31-42, 2012.

[7] Q. Widayati and U. Ependi, "RANCANG BANGUN APLIKASI KAMUS ISTILAH AKUNTANSI PADA," pp. 7-12, 2014.

[8] Aprisa and S. Monalisa, "RANCANG BANGUN SISTEM INFORMASI MONITORING PERKEMBANGAN PROYEK BERBASIS WEB ( STUDI KASUS : PT . INTI PRATAMA SEMESTA )," J. Rekayasa dan Manaj. Sist. Inf., vol. 1, no. 1, pp. 49-54, 2015.

[9] F. Hariadi, "PEMBUATAN SISTEM INFORMASI PERPUSTAKAAN PADA SDN SUKOHARJO PACITAN BERBASIS WEB," IJNS - Indones. J. Netw. Secur., vol. 2, no. 4, pp. 48-54, 2013.

[10] A. N. Cahyanti and B. E. Purnama, "Pembangunan Sistem Informasi Manajemen Puskesmas Pakis Baru Nawangan," J. Speed - Sentra Penelit. Eng. dan Edukasi, vol. 4, no. 4, pp. 17-21, 2012.

[11] A. Supriyatna, "METODE EXTREME PROGRAMMING PADA PEMBANGUNAN WEB APLIKASI SELEKSI PESERTA PELATIHAN KERJA," J. Tek. Inform., vol. 11, no. 1, pp. 1-18, 2018. 